\title{
Patterns of organic lacustrine sedimentation in surroundings of Lake Ladoga and palaeogeographical background.
}

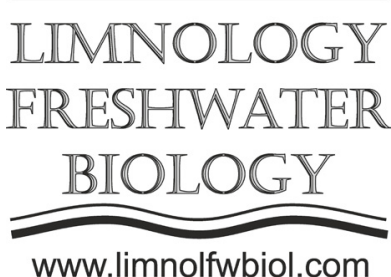

\author{
Kuznetsov D.D. ${ }^{1 *}$, Ludikova A.V. ${ }^{1}$, Subetto D.A. ${ }^{2}$ \\ ${ }^{1}$ Institute of Limnology, Russian Academy of Sciences, Sevastyanova str. 9, St. Petersburg 196105, Russia \\ ${ }^{2}$ Herzen State Pedagogical University of Russia, Moika 48, St. Petersburg, 191186, Russia
}

\begin{abstract}
The study of organic matter dynamics in small lakes sediments in the Lake Ladoga area during the Late Pleistocene - Holocene enabled identifying certain patterns corresponding to the main stages of the paleobasins evolution, from the Baltic Ice Lake, to Lakes Ancylus and Ladoga, and subsequently to the present-day small lakes.
\end{abstract}

Keywords: Holocene, Lake Ladoga, lake sediments, loss on ignition, organic matter

\section{Introduction}

The Holocene dynamics of organic matter (OM) content in lake sediments is of great importance for paleogeographic reconstructions, primarily of the productivity of the aquatic ecosystem and, indirectly, of climatic conditions. Varying proportions of organic and mineral matter in lake sediments are indicative of the processes occurring in the catchment area and the conditions of the surface runoff. The studies of the smalllakes sediments in the North-West of Russia revealed several patterns of changes in the OM content during the Holocene (Kuznetsov, 2016). However, the organic sedimentation in the small lakes that isolated from Lake Ladoga or its paleobasins has certain specifics. A number of present small lakes in the Ladoga-Baltic region emerged due to the Ladoga (or the Baltic) shoreline displacement during the Holocene. The isolation process a certain amount of time, changing a large number of characteristics of the newly formed water body - catchment area, volume of water mass, hydrodynamic conditions, balance characteristics, etc. this led to changes in the conditions of sedimentation. The study presents typical scenarios for the dynamics of organic matter content in the sediments of small lakes that were part of large water basins at the early stages of their development. The sediments of Lake Lavijarvi in the Northern Ladoga region provide an example of a stratigraphic succession of sediments of the lakes isolated from large basins.

\section{Materials and methods}

Sediments cores from small lakes Lavijarvi (North Ladoga area), Laurinlampi (or St Sergey Lake),
Picalalampi, Vuorenlampi, Tervalampi (Putsari Island), Bolshoye Zavetnoye, Uzlovoye (North-West Ladoga area) were collected with the Russian peat corer from the ice or from the special raft (Ludikova et al., 2005; Sapelko et al., 2014; Kuznetsov et al., 2015). The OM content of was estimated as the loss on ignition (LOI). The samples were ignited at a temperature of $500{ }^{\circ} \mathrm{C}$ for 6 hours.

\section{Results}

The thickness of the sediments in the study lakes does not exceed $10 \mathrm{~m}$. The generalized lithostratigraphic succession is as follows. The lower part consists of homogeneous or laminated clays, or sandy clays, overlain by clay gyttja, further transferring into homogeneous or coarse-detritus gyttja. The dynamics of OM content enabled distinguishing several stages of sedimentation, reflecting the large water basins environments and subsequent isolation.

3.9 m-thick sediments of Lake Lavijarvi are clearly divided into 4 units according to the OM content. In the lower clay unit I, the LOI values do not exceed $2 \%$ and do not change. In the unit II, the increase in OM content is observed, and the boundary between the units is also recorded in the lithostratigraphy. The increase in OM is gradual, reaching a maximum of $8 \%$. In the unit III OM content stabilizes ranging from $6 \%$ to $9 \%$ with two clear peaks. Its sharp decrease to $2.5 \%$ reflects to the transition between the units III and IV, and corresponds the distinct boundary between sedimentary units. The unit IV is characterized with increasing OM content. 


\section{Discussion and conclusions}

Generally, the mineral part of the sediments formed during the large-basins stage. Regression of these large basins or tectonical uplift of the area led to the isolation of the former bays and the start of organic sedimentation in their basins. The transitional period may take a long time, while the catastrophic changes in the sedimentation regime are recorded as erosional contacts between the stratigraphic units. The transition from the Baltic Ice Lake sediments is clearly recorded in increasing OM content, while the transition from the Ancylus Lake sediments directly to Lake Ladoga sediments is not always distinguishable because of the gradual increase in OM. However, this transition is clearly reflected in the diatom assemblages composition. The final transformation of the Ladoga bays into the small isolated lakes is distinctly recorded both in sediment stratigraphy, OM content changes and diatom assemblages composition.

In the sediments of Lake Lavijarvi, the stage of the Baltic Ice Lake is clearly distinguished. The transition to the sediments of the Ancylus Lake is clearly expressed by the OM content increase and the lithological boundary. The transition from the Ancylus Lake sediments to Lake Ladoga sediments is not recorded either stratigraphically or in OM content. Therefore the conventional boundary was placed where the LOI reached $6 \%$. The maximum accumulation of OM was observed when the lake basin was occupied by the Ladoga bay. The isolation from Lake Ladoga was accompanied by a drastic restructuring of the sedimentation conditions, as reflected in OM content.

\section{Acknowledgements}

The study contributes to the State Research Program of the Institute of Limnology, RAS (No 01542019-0001), and is partly supported by the RFBR (Grant N 18-05-80087).

\section{References}

Kuznetsov D.D. 2016. Accumulation of organic matter in small lakes of European Russia in the Holocene. In: Materialy IV Vserossijskoj nauchnoj konferencii "Dinamika sovremennih ekosistem v golotsene". Proceedings of the IV all-Russian scientific conference "Dynamics of modern ecosystems in the Holocene", pp. 112-113. (in Russian).

Kuznetsov D.D., Subetto D.A., Sapelko T.V. et al. 2015. Hydrographic network of the northern part of the Karelian Isthmus in the Holocene according to the structure of deposits of small lakes. Geomorphology 1: 54-69. (in Russian).

Ludikova A.V., Subetto D.A., Davydova N.N. et al. 2005. Fluctuations in the level of Lake Ladoga in the Holocene (based on palaeolimnological studies of the St. Sergey Lake on Putsaari Island). Izvestiya RGO. Proceedings of Russian Geographical Society 137-6: 34-41. (in Russian)

Sapelko T.V., Kuznetsov D.D., Korneenkova N.Yu. et al. 2014. Palaeolimnology of internal lakes of Putsaari Island (Lake Ladoga). Izvestiya RGO. Proceedings of Russian Geographical Society 146-3: 29-40. (in Russian) 